\title{
The Evaluation of Teacher Certified Performance in Tulang Bawang Lampung
}

\author{
Sugeng Widodo \\ Lecturer of Faculty of Education and Teacher Training \\ University of Lampung \\ Lampung, Indonesia \\ Corresponding email: sugeng.widodo@fkip.unila.ac.id
}

\begin{abstract}
The focus of this research was to find out the certified teachers' performances of both portfolio test and Education and Training of Teacher Profession (PLPG). The objective of this research was to evaluate the performances of certified teachers. This was a descriptive qualitative research by conducting deep interview to certified teachers and by conducting direct observations in classrooms (classroom supervision) with separating between teachers who passed portfolio test and teachers who graduated the education and training of teacher profession. Samples were taken with stratified sampling. Samples were taken $10 \%$ from each sub district from total population of 286 certified elementary school teachers in Tulang Bawang district. The research results showed that: 1) $82.1 \%$ of teachers were in sufficient criteria in opening lesson, 2) $\mathbf{7 5 . 0 \%}$ teachers were in poor criteria in conducting lesson strategy, 3) $64.4 \%$ teachers were in poor criteria in demonstrating material masteries, 4) $60.7 \%$ teachers were in poor criteria in encouraging students' involvements, 5) $60.7 \%$ teachers were in sufficient criteria in personal communication, and 6) $17.9 \%$ teachers were in good criteria in conducting evaluation of process and result of learning.
\end{abstract}

\section{Keywords-Evaluation, teacher performance, certified teachers}

\section{INTRODUCTION}

The government conducts a teacher certification program as an effort to improve teachers' teaching quality and competence to be professional educators. The teacher certification is an activity to improve teacher's professionalism by providing certificate to those teachers qualified in their academics, competences, mental and physical health, and having abilities in improving national education of Indonesia. The teacher's competences include competences of pedagogic, personality, professionalism, and social. When a teacher is pronounced to pass the certification test, the result can be used as a reference to improve teacher's competence value in the teaching skill (Laczko-Kerr, \& Berliner, D. C, 2002).

Since academic year 2006/2007, the Institute of Teacher's Training (LPTK) had an assignment from the government to conduct certification test for teachers, from kindergarten to high school education (Act of National Education System number 20 in 2003).
The similar certification test model was not the first in the world. Some countries have been conducting the teacher certification test include Japan, Korea, Dutch, Singapore, Australia, United Kingdom, and Hongkong (A Strategy for teacher Quality Improvement, 2008). However, the purpose remains the same; to obtain an assurance that the learning process provided by teachers in the classrooms have quality assurances (York-Barr. J., Ghere. G., \& Sommerness. J, (2007).

These certified teachers are distributed from kindergarten to high school education levels; both public and private schools. After a teacher passing certification test and receiving the certificate, the teacher will be rewarded additional income as much as his/her main salary. By providing this incentive, it is expected that the teacher will perform better in conducting learning process in the classroom. It is the purpose of the teacher certification test. There are two models of certification tests. The first model is the portfolio assessment. If a teacher does not pass this assessment, the teacher will go to the second model; the training model. By this training, the teacher is expected to have performance improvement. In the portfolio assessment model, sometimes there were cases where certification test participants were dishonest. There were indications found by the verification team that portfolio documents were falsified by some teachers (report from portfolio verification team of Lampung University).

The objectives of this paper were to find out the differences of teachers' performances between those teachers passing portfolio model and training model, and to find out the teachers' abilities in conducting their jobs in classrooms.

\section{METHOD}

This was a descriptive qualitative research, with an objective to describe profiles of certified teachers who passed in portfolio assessment model and training model. This research used two types of data. Quantitative data was used to describe percentage of teacher's ability by indicators in the research instruments, and qualitative data was used to describe teacher's performance.

Population was all of 286 elementary school teachers who passed certification tests in both portfolio assessment and 
training (PLPG) and received professional incentives. They were coming from 203 public and private elementary schools. The sample magnitude from each sub district was $10 \%$ from total of certified teachers in the related sub district. This sampling was referred to as purposive sampling (Sudjarwo, 2003: 3). The respondent samples were 28 teachers.

The teacher's performance data were collected directly from observations in classrooms in teaching processes. This research used standard instrument of classroom supervision owned by education office of Tulang bawang.

\section{FINDING AND DISCUSSION}

After observation conducted by the researcher and evaluator, respondent teachers were interviewed deeply by the interviewer team. The objective was to obtain deep information on teachers' performances. Interview data would be combined with observation data. Each of instrument item was scored 1 to 4 . Score of each item was then summed to find average score. Determination of teacher's performance grade (NKG) was based on the average score of each item. This average score was then compared with standard grade for teacher's performance with the following criteria: average score $\leq 1.5=$ poor, average score $1.5-2.5=$ less sufficient, average score $>2.5-3.5=$ sufficient, and average score $>3.5$ $=$ good. The score determination for teacher's performance was based on professionalism; a professional teacher should master learning materials and learning method properly. Table I shows the criteria.

TABLE I. CORE AVERAGE AND CLASSIFICATION OF TEACHER'S PERFORMANCE GRADE

\begin{tabular}{|c|c|}
\hline $\begin{array}{c}\text { Score average of teacher's } \\
\text { performance }\end{array}$ & $\begin{array}{c}\text { Classification of teacher's } \\
\text { performance }\end{array}$ \\
\hline$>3.5$ & Good \\
\hline$>2.5-3.5$ & Sufficient \\
\hline$>1.5-2.5$ & Less sufficient \\
\hline$\leq 1.5$ & Poor \\
\hline
\end{tabular}

The research result indicated that those teachers passed the certification both in portfolio and training models (PLPG). There were 11 teachers passed certification in portfolio assessment model and 17 teachers in training model (PLPG). Average score and its qualitative meaning were used to see the teacher's performance. Table II showed the average score of elementary school teachers' performances in Tulang Bawang.

TABLE II. THE SCORES OF ELEMENTARY SCHOOL TEACHERS' PERFORMANCES IN TULANG BAWANG WHO PASSED CERTIFICATION IN PORTFOLIO AND TRAINING (PLPG) MODELS.

\begin{tabular}{|c|c|c|c|c|c|c|c|c|c|c|c|c|}
\hline \multirow[t]{2}{*}{ Score } & \multicolumn{2}{|c|}{$\begin{array}{l}\text { Ability to open } \\
\text { lesson session }\end{array}$} & \multicolumn{2}{|c|}{$\begin{array}{l}\text { Ability to } \\
\text { perform lesson } \\
\text { strategy }\end{array}$} & \multicolumn{2}{|c|}{$\begin{array}{l}\text { Demonstrating } \\
\text { subject material } \\
\text { mastery }\end{array}$} & \multicolumn{2}{|c|}{$\begin{array}{l}\text { Encouraging } \\
\text { students' } \\
\text { involvements } \\
\text { in learning } \\
\text { process }\end{array}$} & \multicolumn{2}{|c|}{$\begin{array}{l}\text { Interpersonal } \\
\text { communica- } \\
\text { tion }\end{array}$} & \multicolumn{2}{|c|}{$\begin{array}{l}\text { Evaluating } \\
\text { learning } \\
\text { process } \\
\text { and result }\end{array}$} \\
\hline & $\mathrm{fr}$ & $\%$ & fr & $\%$ & fr & $\%$ & fr & $\%$ & fr & $\%$ & $\mathrm{fr}$ & $\%$ \\
\hline$>3.5-4$ & 3 & 10.7 & 1 & 3.6 & 3 & 10.7 & 3 & 10.7 & 11 & 39.3 & 5 & 17.9 \\
\hline$>2.5-3.5$ & 23 & 82.1 & 6 & 21.4 & 7 & 25.0 & 7 & 25.0 & 17 & 60.7 & 20 & 71.4 \\
\hline$>1.5-2.5$ & 2 & 7.1 & 21 & 75.0 & 18 & 64.3 & 17 & 60.7 & 0 & 0 & 3 & 10.7 \\
\hline$\leq 1.5$ & 0 & 0 & 0 & 0 & 0 & 0 & 1 & 3.6 & 0 & 0 & 0 & 0 \\
\hline
\end{tabular}

\section{A. Ability To Open Lesson}

The elementary school teachers' abilities passing certification from portfolio and training (PLPG assessment) models in opening lesson are in sufficient category. This is shown by percentage $82.1 \%$ with average 3.00 score for teachers passing training model (PLPG assessment) and 2.78 score for teachers passing portfolio model. The indicators in opening lesson ability include: doing routine tasks in the classroom such as conditioning students, checking student's presence, doing apperception, and motivating. They are all indicating sufficient category, both for those teachers passing training (PLPG assessment) model and portfolio model. However, some teacher show less sufficient category. Some of them do not yet understand the importance of apperception. Some teachers present their materials directly without a process of opening subject materials properly, and this is caused by less knowledge on the basic teaching technique as results of less teaching training and internal factors of the related teacher.

The indicator of opening lesson provide information of learning objectives. The performances of those teachers passing certification through training (PLPG) model are better than those who passed the certification through portfolio model, because in the training model teachers are provided with guidance and training and to practice directly in the 
learning process, so that their performances improve (Wulandari, 2010).

\section{B. Ability To Perform Learning Strategy}

The abilities of elementary school teachers passing certification from portfolio and training (PLPG) models to perform learning strategy belong to less sufficient category. This is shown with percentage of $75.0 \%$ with average 2.6 score of teachers passing training (PLPG) model and 2.12 score of teachers passing portfolio model.

The indicators of performing learning strategy include: conducting learning method according to basic competences, materials, and students' abilities, situations, conditions, and using supporting/media instruments for learning. Performing learning activities in logical sequences, using learning time efficiently, and using contextual teaching learning (CTL) approach commonly belong to less sufficient category for those teachers passing certification in both portfolio and training (PLPG) models. However, some teachers show sufficient category or close to good category especially for those teacher passing certification in portfolio model. These teachers concern the method to use so that it will be in accordance with students' conditions and situations; they perform learning activities in sequences, and their understanding to CTL learning approach are good. This is possibly because of sufficient knowledge, understanding, and training (Cohen. L., Manion. L, \& Morrison, 2013).

\section{Demonstrating Subject Material Mastery}

The abilities of elementary school teachers passing certification both in portfolio and training (PLPG) models in demonstrating subject material mastery belong to less sufficient category. This is shown with percentage of $64.4 \%$ with average 2.5 score for those teachers passing certification in training (PLPG) model and 2.4 score for those teachers passing certification in portfolio model.

Indicators of abilities in demonstrating subject material mastery include: demonstrating learning materials and involving students in demonstrating subject materials, and these abilities for teachers passing certification in portfolio and training (PLPG) models are less sufficient. However, some teachers passing certification in portfolio model have shown subject material mastery and skillful in demonstrating subject materials. These teachers do not only rely on the text material, but also demonstrate concepts in real forms by using learning media and students are asked to involve in teaching simulation so that they have real experiences of what they learn. This is because teacher's good understanding to mastery of learning material, so that materials are presented properly and relevant to the concepts being presented and students will be able to receive the subject materials comprehensively.

Most of teachers passing certification in training (PLPG) model perform better performances than those teacher passing certification in portfolio model, because the former teachers are provided with guidance in improving material mastery with material experts and learning strategy experts' assistances (Abdullah, 2015).

\section{Encouraging Students' Involvements In Learning Process}

The abilities of elementary school teachers passing certification both in portfolio and training (PLPG) models in encouraging students' involvements in learning process belong to less sufficient category, indicated with percentage of $60.7 \%$ with average 2.60 score for teachers passing certification in training (PLPG) model and 2.43 score for teachers passing certification in portfolio model.

The students' involvements indicators include: encouraging and maintain students' involvements, keeping interactions between teachers and students - and between students and students, improving students' critical thinking ability, and developing students' autonomy attitudes. These indicators commonly belong to less sufficient category for both teachers passing certification in portfolio and training (PLPG) models. Some teachers do not yet provide students freedom to involve active in learning process. Some teachers are still using conventional learning approach where teachers are more active in learning process than students, with one way communication, with teachers as the only knowledge source, and even when teachers cannot attend the class, students cannot go with learning process. In those teachers passing certification in portfolio model, students are more proactive in learning (Biggs, 2011).

\section{E. Interpersonal Communication}

Elementary teachers in Tulang Bawang district passing certification in portfolio and training (PLPG) models are in sufficient category in their interpersonal communication, and this is shown with percentage of $60.7 \%$ with average 3.35 score for teachers passing certification in training (PLPG) model and 3.08 for teacher passing certification in portfolio model.

Indicators in interpersonal communication include: showing open attitude to students' opinions, respecting students' opinions, and praising. These indicators commonly belong to sufficient category for both teachers passing certification in portfolio and training (PLPG) models. However, some teachers have less sufficient category. They do not understand the importance of being open to students and they consider students as empty bottles, so that learning is teacher-centered.

This condition is caused by less knowledge and low basic technique of teaching skill as results of less trainings on learning processes and interval factors from the teachers themselves. This also occurs in indicator of showing flexible attitude in the classroom where the teachers seem to be rigid. Indicator of developing healthy and harmonious interpersonal relationship belong to less sufficient category because the relationship occur in one way only. Certified elementary school teachers show proper and correct use of Indonesian language as the formal language in the classroom. The teachers 
passing certificate in training (PLPG) model have better performances than those from portfolio model. This can be seen from average score on interpersonal communication item of 3.35 versus 3.08 for training-certified and portfolio-certified teachers respectively. Teachers with training (PLPG) certification are provided with guidance and training, so that they experience direct practices in the learning process, and this improves teachers' performances (Hidayat, 2004).

\section{F. Evaluating Learning Process And Result}

One of the most important activities for the teachers' teaching is evaluation, either evaluating learning process or product. $17.9 \%$ training-certified and portfolio-certified elementary school teachers' performances in evaluating learning process and result belong to good category, with average 3.6 score for training-certified teachers and 3.5 score for portfolio-certified teachers. This is caused by good knowledge level on basic technique of teaching skill, besides internal factors from the teachers themselves.

Performances of training-certified teachers are better than portfolio-certified teachers. This can be seen from average scores 3.10 versus 2.81 respectively for item of evaluating learning process and result. Training-certified teachers are provided with guidance and training with direct practices in learning process, so that their experience and performances increase (Eddy, 2009).

\section{CONCLUSIONS AND SUGGESTIONS}

\section{A. Conclusion}

\section{- General}

The performances of certified teachers who received more incentives in Tulang Bawang district could be described as belonging to sufficient category. Most of them showed good performance improvement, and most of those certified teachers obtain their certification from training (PLPG) model. They received training for development both theoretically and in practices for teaching techniques and teaching basic skill.

- Specific

1) Geographical locations do not influence teachers' seriousness in doing their jobs.

2) At the same location, one teacher to another has different performance tendencies.

3) Individual internal factors are more dominant in influencing performance motivation.

4) Teachers with training (PLPG) show better performances compared to those teachers receiving professional certification with their portfolios.

\section{B. Recommendations}

- Those teachers passing professional educator certification should follow with good performance commitment, good dedication, and high loyalty for the job.
- The Education Office should provide good socialization and monitoring, so that teacher certification program obtain the right target, and one of efforts is by improving education quality. Monitoring for certified teachers should be more intensive.

- LPTK should make proper assessment for those teachers eligible for professional certificate, and it should be more selective in passing certification participants.

\section{ACKNOWLEDGMENT}

The author's greatest gratitude goes to Education Office and elementary school principals and teachers in Tulang Bawang district for their permissions and assistances for the author in conducting his research.

\section{REFERENCES}

[1] "Act of Republic of Indonesia About National Education System", Number 20 in 2003

[2] “A Strategy for Teacher Quality Improvement", Draft for Discussion. National Department of Education of Republic of Indonesia, 2008

[3] Abdullah, U, "Learning through Teacher Professional Training: English Teacher Certification Program in Indonesia” Doctoral Dissertation, The Ohio State University, 2015.

[4] Biggs, J, "Teaching for quality learning at university: What the student does", McGraw-Hill Education (UK), 2011

[5] Cohen, \& Morrison, K, "Research methods in education", Routledge, 2013.

[6] Eddy, M, "A Brief History of Somatic Practices and Dance: Historical Development of The Field of Somatic Education and Its Relationship To Dance “, Journal of Dance \& Somatic Practices, 1, 5-27, 2009.

[7] Hidayat, D. S, "Analysis On The Difference Between The Teaching Performance of Certified Teachers And Non-Certified Teachers" Education, 5, 2004.

[8] Laczko-Kerr, \& Berliner, The effectiveness of" Teach for America" and other under-certified teachers, "education policy analysis archives", 10, 37, 2002.

[9] Sudjarwo, "Methodology of Social Research", Mandar Maju: Bandung, 2003

[10] Wulandari " the effect of teacher certification on the quality of English teaching and learning process. Doctoral dissertation sebelas maret university 2010

[11] York-barr. J Gerre \& sommemess "collaborative teaching to increase ELL student learning a three year urban elementary case study" Journal of education for students placed at risk, 12 (3), 301-335,2007. 